\title{
Incentives for the Adoption of E-Government by Greek Municipalities
}

\begin{abstract}
Dimitrios Maditinos $^{1}$, Niki N. Sidiropoulou ${ }^{2}$
Abstract:

Purpose: The research aims to identify the incentives that play an important role in the evolution of e-government in Greece at local scale and its actual development level. It also investigates the factors and the perceived barriers that affect the development of local $e$ government in Greek Municipalities, as well as the benefits they derive from it.

Design/Methodology/Approach: The research is based on a survey that was conducted through a questionnaire to all 325 Municipalities of the country and includes data from 109 Municipalities that participated in the quantitative approach.

Findings: While e-government is spread at a relatively satisfactory level, it appears that only a few Municipalities are performing well. Results highlight also the two main incentives that motivate Municipalities to adopt e-government: The first is the improvement of the efficiency of information exchange with the external environment and the second is managing internal issues-relationships in conjunction with the existence of prominent IT departments. Amongst the main factors that affect e-government adoption by Local authorities, budgetary constraints stand out, while the lack of personnel specialized in Information Technologies is identified as common obstacle.

Practical Implications: Findings suggest that an integrated approach to e-government is needed in order to enable organizations to minimize failures and to overcome barriers and counter risks. The capacity to align e-government applications with the increasing and evolving needs and requirements of the citizens is the key to optimizing the benefits of eGovernment at local scale.

Originality/Value: There is no similar empirical research in the context of Greece; hence, it seems important to increase the knowledge about the drivers of e-government adoption, especially in the public sector at the local scale.
\end{abstract}

Keywords: E-government, municipalities, local authorities, motivations, incentives.

JEL codes:

Paper type: Research paper.

\footnotetext{
${ }^{1}$ Professor, Department of Management Science and Technology, School of Economics and Management, International Hellenic University, Kavala University Campus. dmadi@mst.ihu.gr

${ }^{2}$ Administrator, Department of Management Science and Technology, School of Economics and Management, International Hellenic University, Kavala University Campus nikisidiropoulou@hotmail.com
} 


\section{Introduction}

The Greek public administration is known as a bureaucratic and dysfunctional organization and it has been the subject of numerous reforms aimed at modernizing the state by providing quality services, reducing bureaucracy and costs, increasing transparency and strengthening citizen trust and participation. Over the last few years, the picture has changed positively as attested by improved individual indicators. However, in their daily dealings with citizens, public administration entities continue to provide services that remain time consuming with complicated, inconvenient and not always transparent procedures. In this context, Information and Communication Technologies (ICT) have been used to support the implementation of an e-Government approach that could help bring about a fundamental change in public administration and a drastic amelioration of the services it provides.

In addition to ICT that are widely used in both the public and private sectors, egovernment entails more elements, such as a regular organizational and process review, behavioral change and skill acquisition for the personnel involved in order to enable local public administration to deliver faster and at a lower cost better services to citizens. Although this transformational change often implies a demanding effort it is becoming an urgent priority since putting it off can only lead to a proliferation of the existing problems. E-Governance can be treated as a business strategy, not so much in terms of technology management but as a process, that promotes innovation in services and institutional transformation.

From the literature review and the in-depth study of the reports that were conducted it appears that there is only a limited number of empirical studies that seek to answer questions like: "Under what conditions would the Greek public sector innovate?" and "Which incentives can harness e-government adoption?". The aforementioned questions defined the subject of this study. The article examines the institutional motivations underlying the adoption of e-government by Greek local authorities, the main barriers encountered by projects promoting e-government, the indirect benefits that they generate as well as a wide range of factors that are likely to affect their effective implementation. Its contribution lies in enriching the relevant international literature and taking stock of the current situation through the collection and analysis of empirical data. Results can also help Municipalities, policy makers, citizens and stakeholders to identify and enhance the incentives that will help them to achieve the desired result.

\section{Theoretical background}

\subsection{E-Government}

E-government was introduced and developed by former U.S. Vice President, Al Gore, whose vision was to connect citizens to the numerous governmental agencies and to provide them with full and immediate access (Alketbi, 2018). In the literature, 
there are many variants of the "e-government" or "e-governance" concept. Their difference is that the term "e-government" refers only to services and information provided by the public administration, while the term "e-governance" includes an interaction between organization and stakeholders.

Generally speaking, e-governanment is defined by the use of the internet in public administration in combination with organizational change and innovation which results in the provision of services and information with added value for administrative entities and citizens alike and a positive impact on democratic processes too (Rossel and Finger, 2007, Jun and Weare, 2010). Its benefits include, amongst others (1) the reduction of costs and the improvement of service quality, (2) the reorganization and streamlining of public administration processes, (3) the increase of the efficiency and the effectiveness of services, (4) less time spent by municipal staff on contacts with the public and processing related paperwork thus expanding their availability to support other core activities. E-government is a tool that can bolster democracy and help the fight against corruption as it encourages public participation in the formulation and implementation of policy while it facilitates considerably the transactions of some of the most vulnerable groups with public authorities (Karakykla and Karakyklas, 2013).

\subsection{The Transition from New Public Administration (NPA) to New Public Governance (NPG)}

The need to reduce costs and improve the quality of services through better management and different planning (Hood, 1991) resulted from the 1960s financial crisis and government spending overruns. The main goal was to make public administration more entrepreneurial by saving money, increasing public service efficiency and at the same time make government bureaucrats more accountable and responsive to the needs of users-citizens. This trend, called the New Public Management-NPM, became more pronounced when national governments in various countries launched reform programs in the 1980s (Pollitt and Bouckaert, 2011). One of its main elements of NPM was the introduction of "e-government" supported with the use of modern technology and innovative practices with ultimate objective being to service citizens better and faster and to accelerate economic growth (Andrisani et $a l .$, 2002). In parallel, the New Public Governance (NPG) sought to ensure that "egovernment", besides delivering better results, fully complies with legal requirements while engaging a broad range of social actors in policy formulation and implementation. Hence, NPG relied heavily on a 'network approach' that gave a strong emphasis to 'horizontal' in addition to the traditional "vertical" controls (Pollitt and Bouckaert, 2011).

\subsection{The Diffusion of Innovations}

In recent Government strategies, the term 'modernization' has been replaced by that of 'innovation', which, in practice, is used to include small scale improvements in 
service delivery while distinguishing organizational development from process changes that lead to an improved service to existing users (Griffin, 2007). Diffusion theory focuses on a new technology or an innovation which is spread out to a population of individuals or organizations who decide when to adopt it but also refers to a flow of ideas about the technology that affects the opinion of those who adopted it. The diffusion of new technology is determined by its technological capabilities and impacts, and consequently its usefulness. This implies that in order to understand the diffusion of a new technology someone needs to identify and recognize its impacts and the way it could be useful (Webster, 2007).

The Diffusion of Innovation (DOI) model considers the decision of adopting a new technology as a process of gathering information and reducing uncertainty, while the individual's decision is based upon perceptions of the technology such as relative advantage, compatibility, complexity, trialability and observability. The identified antecedents of a technology usage may differ significantly between a consumer, who adopts technology to receive a service and an employee, who uses technology to perform his job. Resistance to innovation appears to stem from the need for pre-use testing and the uncertainty over after-sales service; moreover, is identified as a key determinant of the innovation diffusion rate, suggesting that organizational features and peer influence play key roles (Gilbert, et al., 2007). Innovation depends, by its nature, on impulse, i.e., bottom-up or top-down, on incentives, on employees and on innovation management. Different initial impetuses can result in differences in the level, shape and direction of innovation, creating conflicts that reflect the differentiated viewpoints and perspectives of people who operate at different hierarchical levels (Windrum, 2008).

The widely spread opinion that the public sector does not innovate and it is only a passive recipient/adopter of innovations, which have been initially developed in the private sector, has been dispelled (Windrum, 2008). The pace of adoption and change sometimes may be slower though because, unlike in the private sector, public institutions have a political layer of accountability and a bureaucracy that inhibits the responsiveness to change since it requires more often than not, a major departure from established routines, up-front expenditures, behavioral changes and entails significant risks (Young, 2015, Jun and Weare, 2011). The bureaucratic state has not been overcome, but its nature and structure change radically as ICT are absorbed by employees in administrations (Fountain, 2006).

\subsection{Previous Studies}

Many previous researches had focused on the development of e-government, implemented on data from different administrative levels such as municipalities, provinces and states. The corresponding conclusions were about website presence, usability problems (Youngblood and MacKiewicz, 2012) or the type of information (Deakins and Dillon, 2002; Criado and Ramilo, 2003; Reddick, 2004; Hahamis et al., 2005; Pina, 2007; Fan, 2011; Criado and Ramilo, 2003; Karkin and Janssen, 
2014; Ruano de la Fuente, 2014). A small number of surveys regarding egovernment dealt with transactions and interactive tools for participation in decisionmaking and planning processes (Fan, 2011; Sandoval-Almazan and Gil-Garcia, 2012, Reggi et al., 2014, Lappas et al., 2015), while others are about vertical and horizontal integration (Fan and Luo, 2014), or about social media activity (Bonsón et al., 2012). Listing the aforementioned results is not relevant here since e-government is a dynamic and not a static process.

Generally, there has been a tendency for researchers to consider particular motivational factors rather than to test the relative importance of a range of incentives. For example, a lot of research has generally concentrated on the role played by organizational, technological (Previtali and Bof, 2009) and related factors that vary according to specific initiatives and frameworks (Arduini et al., 2013). More specifically, researchers examined organizational complexity (GallegoAlvarez et al., 2010), political support (Thompson, 2002; Hahamis et al., 2005; Carrizales et al., 2011, Ma, 2014; van Loon and Toshkov, 2015), commitment (Rose et al., 2015), leadership, employee pressure (Ma, 2013; Warf, 2014), culture and communication strategy (Ford and Murphy, 2008).

Moreover, a large number of researches investigate individual factors such as: per capita income (Youngblood $\kappa \alpha$ MacKiewicz, 2012), type of agency and governance (Moon, 2002; Pina, 2007; Reddick and Norris, 2013b; Bonsón et al., 2015, Feeney and Brown, 2017), geographical location (Nasi et al., 2011), race, metropolitan status (central city, suburban), population size, education (Reddick and Norris, 2013b), lack of knowledge and skills, average age of users (Choudrie et al., 2013), socio-economic status and socio-demographics population characteristics (Lev-On and Steinfeld, 2015), organizational size, internet penetration rate, regional competition (Ma, 2013), communication processes management with other authorities (Hultèn and Björkstrand, 2009), initiation, municipal actualization and rapid scaling-up (Chen et al., 2009) and political stability (Gallego-Alvarez et al., 2010). Microblogging has been studied by Ma (2014) and the use of ICT by Hahamis et al. (2005), while other researchers focused on e-government experience (Reddick and Norris, 2013b), sufficient ICT staff, and a dedicated team (Carrizales et al., 2011, Warf, 2014; Alexopoulos et al., 2018), effective ICT training and support, the ability to organize effective interfaces with end users (Arduini et al., 2010) and finally the implementation and exploitation of funded programs (Goulas and Kontogeorga , 2009).

Some noteworthy results show that the boost to e-government has not led to significant accountability progress (Ruano de la Fuente, 2014) and citizens do not feel safe with e-government applications (Deakins and Dillon, 2002), especially the older users (Beldad et al, 2010). More and more Municipalities are gradually realizing the importance of protecting privacy and security and take relevant measures (Manoharan et al., 2015). To promote e-government initiatives, Municipalities are very likely to interact each other to exchange information for 
better decision-making, while "imitation" processes play an important role (Schedler and Summermatter, 2007; Jun and Weare, 2011) in the elaboration of their development models (Calista et al., 2010; Rooks et al., 2017). It is also important to build appropriate institutional capacity, including strategic plans with clearly defined priorities (Lampathaki et al., 2010; Warf, 2014; Gallego-Alvarez et al., 2010), goals and roles (Xia, 2010), and even a dual strategy for the negative effects of ICT development on social life, work and related areas as well as on civil liberties of users (Garrett, 2005).

Previous studies also confirm that the main obstacle to adoption of e-government is the lack of financial opportunities (Moon, 2002; Beynon-Davies and Martin, 2004; Hahamis et al., 2005; Previtali and Bof, 2009; Kamal et al., 2009; Alexopoulos et al., 2018), since a change at community level requires a huge amount of resources from multiple sources of funding (Chen et al., 2009) and the successful egovernment implementation occurs when the organization provides sufficient funding (Gallego-Alvarez et al., 2010; Warf, 2014; Ma, 2014).

Public participation, although in some cases is not encouraged (Ochara, 2010), improves e-government (Thompson, 2002; Feller et al., 2011; Cegarra-Navarro et al., 2012; Cumbie and Kar, 2016), while regular citizen feedback contributes to the continuous improvement of the design and the type of service provided, promoting more comprehensive and effective governance (Carrizales et al., 2011; SandovalAlmazan and Gil-Garcia, 2012). Most municipalities do not use search methods, while those that use private sector practices are better placed to understand citizen behavior and to predict their future needs (King, 2007). Citizen participation depends on variables that are linked with beliefs and lifestyles, trust in technology, ease of use and perceived usefulness of e-government applications (Rufin et al., 2012; Seo and Bernsen, 2016) while in particular cases the motivations for use are driven by very different needs (Luo and Chea, 2018).

From the above, it is evident that although there has been an increased research in this field over the last 20 years, especially in the field of Local Government and Municipalities, the relative importance of these various factors has not been clarified.

\section{The Proposed Conceptual Framework (Research Hypotheses)}

\subsection{Improving Efficiency}

At the technical level of organizations, contingency theory argues that when efficiency considerations motivate them, then they adjust their organizational structures and tasks to address internal and external uncertainty. This instrumentalrational motivation underlies diffusion theories that assume adoption is influenced by the relative advantages that come from it. In the case of ICT, these benefits increase with the information processing requirements faced by the organization, 
which in turn are affected by the complexity, unpredictability, and interdependence of the organization's internal and external tasks' conditions. (Jun and Weare, 2011). Organizations are generally motivated by the need to improve work efficiency and effectiveness (Feeney and Brown, 2017), something that can be achieved with egovernment initiatives and workplace changes (Moon, 2002). This is because online information reduces administrative burdens and increase efficiency (Ganapati and Reddick, 2014). The development of e-government is also influenced by the internal characteristics and development of public administration and organizational complexity (Gallego-Alvarez et al., 2010; Alexopoulos et al., 2018; Arduini et al., 2013). Thus, it is proposed:

H1: Municipalities motivated by efficiency concerns and internally focused are more likely to be early adopters of Web sites and to adopt a greater range of egovernment services when they face more complex internal environments.

The complexity of the external environment and the impossibility of forecasting increases the information processing requirements. Thus, from an efficiency perspective, the benefits of e-government applications that can disseminate information, serve as communication channels increasing transaction processes and organization's information processing needs (Jun and Weare, 2011). Public organizations, in their attempt to link government structures with citizens and other entities, are expanding through websites, allowing them to pay more attention to citizens' demands (Criado and Ramilo, 2003). The following hypothesis may therefore be formulated as:

H2: Municipalities motivated by efficiency concerns and externally focused are more likely to be early adopters of Web sites and to adopt a greater range of $e$ government services when they face more complex external and challenging environments.

\subsection{Internal Issues: Management, Conflicts and Competition}

Organizations which are focused internally on the managerial level are motivated by concerns about departmental competition. The introduction of Information Technologies has a significant impact on the allocation of resources and power. The fact that e-government technologies reorganize access to information and workflows has a consequent impact on the ability of departments to control their work processes, creating new dependencies on IT departments, turning them into prominent players. The importance of such interdepartmental dynamics has proven to be high because the existing power relationships within organizations substantially determine how new technologies are designed and implemented. Organizations that face intense opposition and complexity in internal structures are more likely to delay the adoption of innovations, as this may entail increasing the span of control by central administrator's management or other opposing sources (Jun and Weare, 2011). In general, organizations do not passively respond to stimuli 
for change but are able to actively drive reform, provided that there is support within the organization (van Loon and Toshkov, 2015), more collaborative work and shared access to information (Baines et al., 2010). The technological development of Municipalities and their administrative complexity largely determine the development of e-government (Gallego-Alvare et al., 2010). Based on the above the third and fourth hypotheses can be formulated as below:

H3: Municipalities motivated by concerns over managing internal bureaucratic politics are less likely to be early adopters of Web sites and to adopt a greater range of e-government services when they have complex internal structures because they are more likely to be constrained by opposition to innovations.

H4: Municipalities motivated by concerns over managing internal bureaucratic politics are more likely to be early adopters of Web sites and to adopt a greater range of e-government services when they have more centralized administrative structures that can help overcome opposition to innovations.

Organizations with strong departments that support a potentially "disruptive" innovation can more easily introduce it. Main beneficiaries and potential supporters of the e-government innovations enable IT departments to advocate for additional resources and create dependencies on the part of other departments. For central administrators, e-government improves their access to information, increasing their influence on departments. Thus, it is expected that Municipalities with more prominent central administrations and IT departments will adopt earlier egovernment. (Jun and Weare, 2011). The following hypothesis may therefore be formulated as:

H5: Municipalities motivated by concerns over managing internal bureaucratic politics are more likely to be early adopters of Web sites and to adopt a greater range of e-government services when they have prominent IT departments that benefit from e-government adoption.

\subsection{Responding to Environmental Demands}

Organizations with an external orientation are motivated by demands from the external environment, such as elected officials courting voters or administration officials with an interest to develop service-oriented programs geared to popular needs. Because the costs and benefits of web applications are widely distributed, their supply is linked to issues that are of concern for the majority of citizens and therefore depend on broad constituent support. Thus, stakeholders with a higher socioeconomic standing, who tend to use the internet more widely and require upgraded public services, are more likely to support such initiatives (Jun and Weare, 2011). Governments worldwide recognize ICTs as powerful tools for enhancing citizen engagement in public policy-making and as a way of enhancing citizen trust in governments (Pina et al., 2007). Cities with more technologically sophisticated 
residents may be more willing to address the needs of their constituents (Calista et $a l ., 2010)$. The adoption of social media applications for public relations purposes, such as promoting a positive organizational image, is also becoming more widely acknowledged tool enabling governments to connect with increasingly diverse constituencies and promote collaborative governance with citizens and stakeholders (Bennett, 2017). Stated as hypothesis:

H6: Municipalities motivated by constituent demands are more likely to be early adopters of Web sites and to adopt a greater range of e-government services when they serve populations with a higher socioeconomic status.

Emulation effects and competitive pressures, especially in the presence of political race at the local level, can affect the number of e-government providers (Arduini et al., 2010). Municipalities may be inclined to compete with their counterparts in order to win in an economic and political race which represents a substantial incentive for local authorities to adopt innovation as a competitive advantage. Horizontal competition affects adoption more than vertical, while regional competition and top-tier pressure are positively and significantly associated with the likelihood of launching innovations and early e-government adoption (Ma, 2013; 2014). This environmental pressure can often come from the expectations of citizens (Homburg et al., 2014), while local authorities are more likely to adopt innovations if their neighboring counterparts have already embraced them. (Jun and Weare, 2011). Therefore, the next hypothesis can be formulated as follows:

H7: Municipalities motivated by competition from nearby jurisdictions are more likely to be early adopters of web sites and to adopt a greater range of e-government services when their neighbors offer e-government services.

\subsection{Legitimation}

At the institutional level, organizations must be perceived as politically legitimate which requires that they conform to social expectations concerning organizational form and functions. These expectations often lead them to adopt structures and practices that are socially acceptable and credible even if they do not necessarily improve technical performance. Web sites have the characteristic of being accessible and therefore visible, leading Municipalities to undertake activities in accordance with current social standards and practices (Jun and Weare, 2011). Persuasive institutional pressure together with the formulation of public views and collective knowledge are crucial to the innovation of e-government (Homburg et al., 2014) because they contribute to the improvement of the quality of services for citizens and increase their legitimacy and trust (Bernhard and Wihlborg, 2015)

Municipalities are affected by higher levels of government as well as by normative and mimetic pressures arise from widespread comparisons and rankings of egovernment practices. The desire to attain institutional legitimacy through e- 
government adoption has noticeable effects on the diffusion pattern among municipalities. Early adopters are not influenced by institutional pressures because social expectations within their organizational field have not been established. As the number of adopters among peer organizations increase, expectations for such practices are gradually established and lagging organizations feel obliged to meet them in order not to lose their legitimacy (Jun and Weare, 2011). Initiatives of this kind require legitimacy to justify investment, action by the political personnel and adequate speed in the political decision-making process (Rooks et al., 2017). The following hypotheses can be proposed:

H8: Municipalities motivated to attain institutional legitimacy are more likely to adopt Web sites and a greater range of e-government services when neighboring municipalities offer e-government services, creating pressures to conform to developing norms.

H9: For municipalities that are motivated to attain institutional legitimacy, the factors that promote early adoption of Web sites when social norms of behavior have not yet been established will diminish in importance for later adopters that respond primarily to the social expectations created by the earlier adopters.

\subsection{The role of Vendors}

Outside vendors are obviously playing a prominent role in the formation and execution of e-government strategies despite the fact that Municipalities are treated as unitary actors with a given set of motivations. On the one hand, there are vendors who provide information on how e-government services can help a municipality achieve its goals without affecting the fundamental goals. In this case, vendors reinforce and strengthen existing organizational motivations to innovate. On the other hand, from a socio-psychological perspective, when sales pitches contain not only information but also affective pleas targeted at changing attitudes and addressing perceived social pressures, then greater interaction may cause a shift in key organizational motivations (Jun and Weare, 2011).

In the case of small municipalities lacking sufficient ICT skills and knowledge to manage relations with IT vendors (partner selection and software), IT governance is de facto delegated to third parties, with the risk of even being exposed to opportunistic behaviors (Previtali and Bof, 2009). As organizations perceive the priority flagging of web site development and management there is an increase in outsourcing practices. This is attributed to the lack of technical skills whereas in large municipalities the deficit of technical skills does not usually attain this high level (Ferro and Sorrentino, 2010). Therefore, a hypothesis can be formulated as follows:

H10: When vendors act primarily employed as sources of information, greater reliance on outsourcing strengthens municipalities' existing motivations for the 
adoption of a greater range of e-government services.

H11: When vendors influence the base motivations of municipalities, greater reliance on outsourcing will diminish the impact of municipalities' existing motivations on the adoption of a greater range of e-government services.

Figure 1. The proposed conceptual framework of the study

\begin{tabular}{|l|l|}
\hline $\begin{array}{l}\text { Internal } \\
\text { efficiency of internal } \\
\text { information flow }\end{array}$ \\
\hline $\begin{array}{l}\text { Internal issues } \\
\text { relationships } \\
\text { management in complex } \\
\text { internal structures }\end{array}$ \\
\hline $\begin{array}{l}\text { Management of internal } \\
\text { issues / relationships in } \\
\text { centralized internal } \\
\text { structures }\end{array}$ \\
\hline $\begin{array}{l}\text { Management of } \\
\text { internal issues / } \\
\text { relationships and the } \\
\text { existence of prominent } \\
\text { ICT departments }\end{array}$ \\
\hline $\begin{array}{l}\text { Vendors who reinforce } \\
\text { existing motivations } \\
\text { base motivations }\end{array}$
\end{tabular}

\section{Research Methodology}

\subsection{The Population of the Study}

In order to adequately answer the key research issues of this study, a systematic review of the existing literature was conducted and the article of Jun and Weare (2011) was the base for the proposed conceptual framework that was developed. The sampling frame was decided to focus on Municipalities, which is an appropriate empirical framework for the research objectives. Municipalities are considered to be 
the closest tier (level) of government to citizens because they are mostly concerned with the daily life of people (Cegarra-Navarro et al., 2012). Besides, municipalities have a variety of possible interactions between them and citizens (Bonsón et al., 2015). It was also considered appropriate for the sampling approach to be nonlimited, viewing the 325 Greek Municipalities as a whole. Municipalities in Greece are located in all 13 Regions, 65 of them are situated in islands, covering $18.7 \%$ of the country's surface. The largest municipality has 664.046 inhabitants while the smallest one has 152 . This diversity poses some challenges in the analysis due to their different characteristics (Sandoval-Almazan and Gil-Garcia, 2012).

\subsection{Measurement}

The present empirical study was conducted using a newly created structured questionnaire based on the Jun and Weare (2011) research and the questionnaires from the International City / Country Management Association-ICMA (years 2000, 2002 and 2004). They were adapted to the Greek context and include elements from the literature review. Indicatively, the questionnaire contains 42 questions that compose eleven individual factors. The first six factors refer to the internal environment while the other five refer to the external environment. Each of the 11 factors consists of 3 to 7 multiple choice questions and the five-point Likert scale was used to measure factors, in most of the cases. The questionnaire also consists of eight sections, from which the first two include general elements about the Municipalities and the next sections explore the provision of non-specific egovernment services, while the rest were used to measure the 11 factors of the study, as mentioned before. The last section includes 38 questions about e-government services provided by each municipality.

To examine the organizational, environmental, and socio-economic characteristics of the Municipalities, data were collected about Municipal revenue (Diavgeia ${ }^{3}$, year 2011), population, employment rate, education and GDP per Regional Unit (ELSTAT $\left.{ }^{4}, 2011\right)$ and average household income per municipality (Petroudis, 2017). Table 1 provides explanations of the variables and of the descriptive statistics.

\subsection{Sample and Data Collection}

As previously mentioned, primary data set were collected electronically from a sample containing all Municipalities whose e-mail addresses were obtained from the official website of the Ministry of Interior or of the Municipalities.

\footnotetext{
${ }^{3}$ The Transparency or Transparency Program was created by Law 3861/2010 and is created for posts online on a central website by government bodies and management on the Internet. Public authorities, public and private sector bodies, and Independent Authorities, as well as first- and second-degree Local Authorities required publishing.

${ }^{4}$ The Hellenic Statistical Authority (ELSTAT) is the national statistical office of Greece.
} 
Table 1. Descriptive statistics

\begin{tabular}{|c|c|c|c|c|c|c|}
\hline Variable & Measurement & $\mathbf{N}$ & Min & $\operatorname{Max}$ & Mean & SD (S) \\
\hline $\begin{array}{l}\text { Mean } \\
\text { adoption }\end{array}$ & $\begin{array}{l}\text { Average number of e- } \\
\text { government services }\end{array}$ & 109 & 6 & 37 & 19 & 6,32 \\
\hline \multicolumn{7}{|c|}{ Environmental factors } \\
\hline Population & Municipal population & 109 & 185 & 664.046 & 27.556 & 73.150 \\
\hline $\begin{array}{l}\text { Central, } \\
\text { Suburb }\end{array}$ & Suburb (0), Central (1) & 109 & 0 & 1 & 0,35 & 0,479 \\
\hline $\begin{array}{l}\text { Geographic } \\
\text { al location }\end{array}$ & North (0), South (1) & 109 & 0 & 1 & 0,49 & 0,502 \\
\hline Island & No $(0)$, Yes $(1)$ & 109 & 0 & 1 & 0,18 & 0,389 \\
\hline \multicolumn{7}{|c|}{ Organizational factor } \\
\hline $\begin{array}{l}\text { Organizatio } \\
\mathrm{n} \text { size }\end{array}$ & Total employees & 99 & 4 & 2.500 & 170 & 334,44 \\
\hline $\begin{array}{l}\text { IT } \\
\text { department }\end{array}$ & No $(0)$, Yes $(1)$ & 109 & 0 & 1 & 0,679 & 0,469 \\
\hline $\begin{array}{l}\text { Fiscal } \\
\text { capacity }\end{array}$ & $\begin{array}{l}\text { Municipal revenue (thous., } \\
\text { year 2011) }\end{array}$ & 102 & 1.198 & 547.467 & 32.837 & 70.399 \\
\hline $\begin{array}{l}\text { Administrati } \\
\text { ve } \\
\text { centralizatio } \\
\mathrm{n}\end{array}$ & $\begin{array}{l}\text { Percentage of municipality } \\
\text { employment devoted to } \\
\text { central finance and } \\
\text { administration }\end{array}$ & 96 & 1 & 170 & 37 & 31,95 \\
\hline $\begin{array}{l}\text { Web site } \\
\text { managemen } \\
\mathrm{t}\end{array}$ & $\begin{array}{l}\text { Responsibility for Web site } \\
\text { management to Mayor or } \\
\text { Special Advisors or Secretary } \\
\text { General or External } \\
\text { consultants (0), IT } \\
\text { department, } \\
\text { Finance/Administration } \\
\text { department (1) }\end{array}$ & 95 & 0 & 1 & 0,59 & 0,495 \\
\hline $\begin{array}{l}\text { ICT -e- } \\
\text { government } \\
\text { budget }\end{array}$ & $\begin{array}{l}\text { Current use budget for ICT } \\
\text { and e-government }\end{array}$ & 105 & $<5.000$ & $>50.000$ & 3,43 & 1,525 \\
\hline $\begin{array}{l}\text { General } \\
\text { Director }\end{array}$ & \multirow{3}{*}{$\begin{array}{l}\text { Form of government } \\
\text { - Nonexistence }(0) \text {, existence } \\
\text { (1) }\end{array}$} & 106 & 0 & 1 & 0,00 & 0,2495 \\
\hline $\begin{array}{l}\text { Secretary } \\
\text { General }\end{array}$ & & 109 & 0 & 1 & 1 & 0,5013 \\
\hline $\begin{array}{l}\text { Special } \\
\text { consultants }\end{array}$ & & 108 & 0 & 1 & 1 & 0,2111 \\
\hline \multicolumn{7}{|c|}{ Socio-economics factors } \\
\hline $\begin{array}{l}\text { Employmen } \\
\mathrm{t}\end{array}$ & $\begin{array}{l}\text { Employment percentage per } \\
\text { Municipality }\end{array}$ & 109 & 0,21 & 0,48 & 0,325 & 0,0486 \\
\hline Education & $\begin{array}{l}\text { Education percentage per } \\
\text { Municipality }\end{array}$ & 109 & 0,02 & 0,48 & 0,11 & 0,07 \\
\hline $\begin{array}{l}\text { GDP per } \\
\text { capita }\end{array}$ & $\begin{array}{l}\text { GDP per capita per Regional } \\
\text { unit }\end{array}$ & 109 & 10.355 & 33.845 & 14.789 & $5.512,42$ \\
\hline $\begin{array}{l}\text { Average } \\
\text { household } \\
\text { income }\end{array}$ & $\begin{array}{l}\text { Average household income } \\
\text { per Municipality (2011) }\end{array}$ & 109 & 11.657 & 56.866 & 17.757 & 5.300 \\
\hline
\end{tabular}

The questionnaire was uploaded online (using Google drive) and the link was forwarded online to 325 Municipalities over a three-month period (from 22 February 
to 11 July 2019). As a result of the municipal elections, 3 extensions were given for obtaining a more satisfactory response rate. In total, 728 e-mails were sent and also numerous telephone communication took place, leading to 113 responses. Incomplete or invalid questionnaires were discarded, leaving 109 valid questionnaires (rate $33.53 \%$ ).

\subsection{Validity and Reliability}

The research tool was tested, both in terms of content and validity. The content validity test was conducted prior to the empirical survey. Specifically, the tool was discussed, in an interview process, with employees and Heads of Departments of 2 Municipalities, incorporating all the proposed modifications before finalizing the questionnaire. In order to examine the validity of its structure, each of the appropriate 11 factors was evaluated for its unidimensionality and reliabity. The structure of the questionnaire was validated by the Exploratory Factor Analysis (EFA) method and then the reliability of the extracted factors was tested using the Cronbach's Alpha index. All tests concluded that the scales used were valid and reliable (see Tables 2 and 3 for the main results).

Table 2. Estimation of unidimensionality and reliability of internal environmental factors

\begin{tabular}{|c|c|c|c|c|c|}
\hline Factors & $\begin{array}{c}\mathbf{K M} \\
\mathbf{O}\end{array}$ & $\begin{array}{c}\text { Bartlett' } \\
\text { s Test of } \\
\text { Sphericit } \\
\text { y }\end{array}$ & $\begin{array}{l}\text { Eigen- } \\
\text { value }\end{array}$ & $\begin{array}{c}\text { Total } \\
\text { Variance } \\
\text { Explained }\end{array}$ & $\begin{array}{c}\text { Cronbach's } \\
\text { Alpha }\end{array}$ \\
\hline $\begin{array}{l}\text { Improving the } \\
\text { efficiency of internal } \\
\text { information flow }\end{array}$ & \multirow{6}{*}{0,764} & \multirow{6}{*}{858,137} & 5,985 & 29,924 & 0,760 \\
\hline $\begin{array}{l}\text { Management of } \\
\text { internal issues } \\
\text { /relationships in } \\
\text { complex internal } \\
\text { structures }\end{array}$ & & & 2,748 & 43,663 & 0,605 \\
\hline $\begin{array}{l}\text { Management of } \\
\text { internal issues / } \\
\text { relationships in } \\
\text { centralized internal } \\
\text { structures }\end{array}$ & & & 1,890 & 53,112 & 0,682 \\
\hline $\begin{array}{l}\text { Management of } \\
\text { internal issues / } \\
\text { relationships and the } \\
\text { existence of prominent } \\
\text { ICT departments }\end{array}$ & & & 1,618 & 61,200 & 0,886 \\
\hline $\begin{array}{l}\text { Vendors who reinforce } \\
\text { existing motives }\end{array}$ & & & 1,091 & 66,655 & 0,696 \\
\hline $\begin{array}{l}\text { Vendors who influence } \\
\text { key motives }\end{array}$ & & & 0,995 & 71,630 & 0,667 \\
\hline
\end{tabular}


Table 3. Estimation of unidimensionality and reliability of external environmental factors

\begin{tabular}{|c|c|c|c|c|c|}
\hline Factors & KMO & $\begin{array}{c}\text { Bartlett's } \\
\text { Test of } \\
\text { Sphericity }\end{array}$ & $\begin{array}{l}\text { Eigen- } \\
\text { value }\end{array}$ & $\begin{array}{c}\text { Total } \\
\text { Variance } \\
\text { Explained }\end{array}$ & $\begin{array}{c}\text { Cronbach's } \\
\text { Alpha }\end{array}$ \\
\hline $\begin{array}{l}\text { Improving the } \\
\text { efficiency of } \\
\text { information } \\
\text { exchange with the } \\
\text { external } \\
\text { environment }\end{array}$ & \multirow{5}{*}{0,854} & \multirow{5}{*}{1191,948} & 9,317 & 42,350 & 0,769 \\
\hline $\begin{array}{l}\text { Meeting the voters } \\
\text { - citizens' demands }\end{array}$ & & & 2,649 & 54,389 & 0,901 \\
\hline $\begin{array}{l}\text { Competition } \\
\text { between peer } \\
\text { organizations }\end{array}$ & & & 1,262 & 60,125 & 0,704 \\
\hline $\begin{array}{l}\text { Institutional } \\
\text { legitimacy arising } \\
\text { from pressures to } \\
\text { comply with } \\
\text { evolving standards }\end{array}$ & & & 1,150 & 65,353 & 0,869 \\
\hline $\begin{array}{l}\text { Institutional } \\
\text { legitimacy } \\
\text { resulting from } \\
\text { social expectations }\end{array}$ & & & 0,933 & 69,592 & 0,774 \\
\hline
\end{tabular}

\section{Empirical Findings}

\subsection{Descriptive Statistics}

Table 1 in Appendix presents the current status of Municipalities with respect to egovernment ranking. First came the Municipality of Molos Ag. Konstantinou, having adopted e-government for 37 out of the 38 possible services while the Municipalities of Aigina and Samothraki had the lowest score (6/38). All Municipalities have created a web site over the past decade providing e-government services, while $57.8 \%$ provide these services also though physical presence or mail. A separate IT department is found in 74 Municipalities (67.9\%) with the number of employees usually ranging from 1to $3(65.1 \%)$ while in $46.7 \%$ of the cases it is the department with exclusive competence. Next, regarding the ICT-eGovernment budget for Municipalities, the largest percentage (33.9\%) is found in " $>50.000,00 € "$ category and $46.8 \%$ of them finances these activities from "own resources". Lastly, one-fourth of them (24.7\%) have developed their e-government services using both vendors and Municipality' staff.

Almost half of them (46.2\%) elaborated "Some actions utilizing ICT and egovernment" in the context of overall Municipal strategic planning while it must be pointed that 43 out of 109 do not have a comprehensive strategic plan at all. The 
survey also revealed that only $7.3 \%$ conducted a citizen survey to determine the type of e-services to be developed. The most common problems faced by Municipalities were "Lack of personnel technology / web" (75.7\%) and "Lack of technology / web specialization" (48.6\%). Concerning the change that e-Government actually brought to municipalities, "Improving Citizens' Service" (69.7\%) and "Improving Municipality's Communication with the Public" (64.0\%) emerged as the frontrunners.

\subsection{Regression Analysis}

With respect to the explanatory factors, the multiple linear regression technique was used to explain the relationship between the expected value of dependent variable (Adoption of e-government) from the values of 11 independent variables. Specifically, two models for multiple regression analysis were conducted for the independent variables, for both internal and external environment. For the internal environment, the coefficient of determination was $R^{2}=0.195$ (or 19.5\%). It was not so high and satisfactory, showing that only $19.5 \%$ of the total variability is interpreted by regression. This is not a major problem though since the purpose of the analysis is not to predict the values of the dependent variable but to investigate the effect of the independent variables on it (Field, 2009). Regression is also significant at the $5 \%$ level of significance $(F=3.712, p=0.002<0.05)$ which explains that at least one of the independent variables appears to have a significant effect on the dependent variable.

Table 4. Estimated regression coefficients Internal Environment

External Environment

\begin{tabular}{|c|c|c|c|c|c|c|c|}
\hline & Beta & $\mathrm{t}$ & Sig. & & Beta & $\mathrm{t}$ & Sig. \\
\hline Variable & & 1,777 & 0,079 & Variable & & 30,914 & 0,000 \\
\hline $\begin{array}{l}\text { Improving the efficiency } \\
\text { of internal information } \\
\text { flow }\end{array}$ & 0,184 & 1,477 & 0,143 & $\begin{array}{l}\text { Improving the } \\
\text { efficiency of } \\
\text { information } \\
\text { exchange with the } \\
\text { external } \\
\text { environment }\end{array}$ & 0,429 & 3,509 & 0,001 \\
\hline $\begin{array}{l}\text { Management of internal } \\
\text { issues /relationships in } \\
\text { complex internal } \\
\text { structures }\end{array}$ & 0,003 & 0,027 & 0,978 & $\begin{array}{l}\text { Meeting the voters - } \\
\text { citizens' demands }\end{array}$ & 0,034 & 0,315 & 0,754 \\
\hline $\begin{array}{l}\text { Management of internal } \\
\text { issues / relationships in } \\
\text { centralized internal } \\
\text { structures }\end{array}$ & $-0,026$ & $-0,217$ & 0,828 & $\begin{array}{l}\text { Competition } \\
\text { between peer } \\
\text { organizations }\end{array}$ & 0,073 & 0,632 & 0,529 \\
\hline $\begin{array}{l}\text { Management of internal } \\
\text { issues / relationships and } \\
\text { the existence of } \\
\text { prominent ICT } \\
\text { departments }\end{array}$ & 0,302 & 2,745 & 0,007 & $\begin{array}{l}\text { Institutional } \\
\text { legitimacy arising } \\
\text { from pressures to } \\
\text { comply with } \\
\text { evolving standards }\end{array}$ & 0,016 & 0,092 & 0,927 \\
\hline
\end{tabular}




\begin{tabular}{|c|c|c|c|c|c|c|c|}
\hline $\begin{array}{l}\text { Vendors who reinforce } \\
\text { existing motives }\end{array}$ & 0,060 & 0,364 & 0,717 & $\begin{array}{l}\text { Institutional } \\
\text { legitimacy resulting } \\
\text { from social } \\
\text { expectations }\end{array}$ & 0,045 & 0,264 & 0,792 \\
\hline $\begin{array}{l}\text { Vendors who influence } \\
\text { key motives }\end{array}$ & 0,021 & 0,133 & 0,895 & & & & \\
\hline
\end{tabular}

\subsubsection{Dependent variable: e-government adoption}

Table 4 shows that in the internal environment only the independent variable "Management of internal issues / relationships and the existence of prominent ICT departments" at the $5 \%$ significance level $(\mathrm{t}=1,827$ with $\mathrm{p}=0.007<0.05)$ had a significant and positive effect on e-government adoption.

For the external environment, the coefficient of determination $\mathrm{R}^{2}$ is 0.228 , also not so satisfactory, which means that only $28.4 \%$ of total variability is interpreted by regression. This, as mentioned in the previous case, is not a major problem. Regression is also significant at the $5 \%$ level of significance $(F=7.781, p=0.000$ $<0.05)$ meaning that at least one of the independent variables appears to have a significant effect on the dependent variable.

Amongst the variables related to the external environment, only the independent variable "Improving the efficiency of the exchange of information with the external environment" at the 5\% significance level had a significant and positive effect $(\mathrm{t}=$ 3.509 with $\mathrm{p}=0.001<0.05$ ). This means that this is also the only variable related to the external environment that is important in determining the extent to which Municipalities adopt e-government. Except for this variable that has a positive and significant effect $(\mathrm{B}>0$ and $\mathrm{p}<0.05)$, the table shows that all other "external environment" variables have a positive effect (B>0) on the adoption of eGovernment but not significant ( $\mathrm{p}>0.05)$.

Except for the variable that has a positive and significant effect $(\mathrm{B}>0$ and $\mathrm{p}<0.05)$, Table 4 shows that almost all "internal environment" variables, with the exception of "management internal issues - relationships in centralized structures", have a positive $(B>0)$ effect on the Municipalities e-government adoption but not significant $(\mathrm{p}>0.05)$.

Table 5. Hypotheses testing results

\begin{tabular}{|l|l|l|l|}
\hline Hypothesis & Remarks & Hypothesis & Remarks \\
\hline H1 & Accepted & H7 & Accepted \\
\hline H2 & Totally accepted & H8 & Accepted \\
\hline H3 & Accepted & H9 & Accepted \\
\hline H4 & Rejected & H10 & Accepted \\
\hline H5 & Totally accepted & H11 & Accepted \\
\hline H6 & Accepted & & \\
\hline
\end{tabular}




\subsection{Factors Affecting E-Government Development}

In addition to the incentives that motivate Municipalities, the availability of egovernment services is influenced by other factors which, according to the literature review, can be grouped into 3 categories: environmental, organizational and socioeconomic factors. One-way analysis of variance (One Way Anova) was performed to investigate the differences, while the degree of interdependence of the variables was measured with correlation analysis.

\subsubsection{Environmental factors}

For the "Population" factor, there are 4 levels (0-25.000, 25.001-50.000, 50.001100.000 and $>100,000)$ with only $5 \%$ significance level $(\mathrm{F}=2,54$, p-value $=0.06>$ $0.05)$ and therefore there are no statistically significant differences. Duncan's multiple comparisons indicate that cities with bigger populations do not tend to develop e-governance more than municipalities with a smaller or much smaller population.

The next environmental factors to be examined through correlation analysis are "Geographical Location", "Island" and "Metropolitan - Suburb Municipality" in order to determine the degree of interdependence of the variables under consideration. For the "Geographical location", the Pearson coefficient is $(r=0.009)$, $\operatorname{sig}=0.927>0.05$ and therefore no significant linear correlation can be established, the same is true for "Island" where Pearson $r=-0.126$ and sig $=0.193>0.05$. For the "Metropolitan -Suburb Municipality", a statistically significant linear correlation is shown as Pearson $r=0,200$ and sig $=0.037<0.05$.

\subsubsection{Organizational factors}

For the "Budget for ICT and e-government in the current year", five levels were categorized $(<5,000 €, 5,000-10,000 €, 10,000-25,000 €, 25,000-50,000 €$ and $>$ $50,000 €)$. The results showed that analysis is significant at the $5 \%$ level of significance $(\mathrm{F}=4,154$ with $\mathrm{p}$-value $=0.004<0.05)$ indicating that there are differences between the budget for ICT and e-government that is spent by Municipalities. Duncan's multiple comparisons show that Municipalities that spend more on ICT and e-government show the highest average adoption of e-government.

Concerning the "financial capacity" of Municipalities (revenue 2011) at seven levels and in thousands $(<10,000 €, 10.001-20.000 €, 20.001-30.000 €, 30.001-40.000 €$, $40.001-50.000,50.001-100.000$ and $>100.001 €)$, results showed that analysis is significant $(\mathrm{F}=4,300$ with $\mathrm{p}$-value $=0.001<0.05)$ and there were statistically significant differences between groups means as determined by One Way Anova analysis. Duncan's multiple comparisons show that Municipalities whose revenues are at a higher level also have higher average e-government adoption.

For the organizational factors "Entity Size", "Existence of ICT department", "Administrative centralization" and "Web site management", examined by 
correlation analysis, the results showed that there was no statistically significant linear correlation. This is because the Pearson correlation coefficient $(\mathrm{r}=0.0116, \mathrm{r}=$ $0.093, r=-0.025$ and $r=0.063$, respectively) is very close to 0 and furthermore the $\mathrm{p}$-value for the two-sided control is $0.2251>0,05,0.338>0.05,0.809>0.05$ and $0.543>0.05$, respectively.

\subsubsection{Socio-economic factors}

The first of the socio-economic factors is the "GDP per Regional Unit", with five levels $\quad(10,000-15,000 € \quad 15.001-20.000 € \quad 20.001-25.000 € \quad 25.001-30.000$ and $>30.001$ ). Results showed that the analysis was not significant at the $5 \%$ level of significance $(\mathrm{F}=2,371$ with $\mathrm{p}$-value $=0.057>0.05)$ indicating that there were no statistically significant differences between the means of the groups as determined by One Way Anova analysis. Duncan's multiple comparisons show that Municipalities belonging to Regional High-GDP Peripheral Units have not further developed e-government.

For the variables "Employment", "Education", and "Average annual household income", correlation analysis results showed that there is a statistically significant mediate, linear correlation for the first two factors because Pearson's correlation coefficient $(r=0.225, r=0.233$ and $r=0.188$, respectively) is very close to 0.2 and in addition the $\mathrm{p}$-value for the two-sided test is $0.008<0.05,0.015<0.05$ and $0.051>0.05$ respectively.

\section{Conclusions}

The first result apparent from the empirical analysis is that the adoption of egovernment by Greek local authorities follows quite the pattern found in the literature. Research results indicate that some services with institutional content or related to one-way information have been developed to a greater range than others, such as services related to participation (Appendix Table 2). Among them there are services similar to those that emerged from Costopoulou et al. (2017) research. According to the municipalities' ratings, it is concluded that $52.3 \%$ of the respondents are above the average level of e-government, out of the 38 services set to assess the level of development, provide at least 19.

Though there are many studies about e-government evaluation in literature, there is a scarcity in examining organizations' motivations for the adoption of e-government. The results of this research show clearly that one of the main motivations of Municipalities in Greece for the adoption of e-government services is to improve the efficiency of information sharing with the external environment. The information sharing and common use of them enhance the administrative' processes, while in cases that organizations have an external orientation, the e-government website could be a starting point for a multitude of interactions with citizens (SandovalAlmazan and Gil-Garcia, 2012). E-government enables organizations to provide better services and integrated information, to improve performance in order to 
achieve higher efficiency and effectiveness and thereby to increase citizen participation and consequently increase their satisfaction and confidence in the organization (Manoharan et al., 2015). E-services could be initially used as a tool for specifying citizen needs, through discussion forums, that will help organizations to provide relevant information and services.

Consequently, public administrations become more efficient as citizen needs are met while the organizations achieve cost reduction and higher revenues. The amount of information provided through websites enables citizens to evaluate in a better way the accountability of the organization (Bolivary, 2018). From the side of the demand, the benefits involve mainly increased organization transparency, effectiveness and efficiency leading to a system that fosters the professional interests of its constituencies. Therefore, from the demand side stance the interest lies in the implementation of a transparency-enabling information system. Although not involved in the implementation of the system, the supply side can support it as well since it facilitates modern, new public services and reduces corruption (Gritzalis, Tsohou and Lambrinoudakis, 2017).

Another key incentive for adopting e-government services is the management of internal issues when there is a prominent ICT department. E-government should be responsibility of a single unit, of an IT department capable to connect and collaborate with all the other parts of the organization. Such a form of organization could include a dedicated committee or a working group that will integrate the other units in the e-government planning process. In general, IT and e-governance deal with the complex relationship between political governance and IT management, including different cultures, frequent misunderstandings and mistrust. If the initiative for innovation comes from elected officials, initiators would be well advised to get into contact with the IT managers. If the initiative arises in the IT management context, the managers in turn should consult relevant elected people, whose approval will be needed for budgeting and/or authorization later on (Kubicek, et al., 2011). There is a need for an ICT department in charge of e-government with its own budget that would allow it to confront internal competition among departments for fiscal resources and empower municipalities to have a more developed egovernment and interact more with the public (Reddick, 2007).

This study identified the barriers faced by municipalities and the most significant finding was the shortage of staff (Moon, 2002) as the overwhelming majority of municipalities employ 1 to 3 people for the development and implementation of egovernment services. Another major barrier to improving the performance of the egovernment is the lack of appropriate skills in the workforce (Moon, 2002; Hahamis et al., 2005; Ganapati and Reddick, 2014; Alexopoulos et al., 2018). Also, the need for technology upgrades is a reality for the greek Municipalities, as also observed by Goulas and Kontogeorga (2009). Although most Municipalities declared that more than $€ 50,000.00$ is spent on ICT and e-government, the lack of financial resources, as pointed out in the responses of the Municipal Representatives remains an 
impediment (Moon, 2002; Beynon-Davies and Martin, 2004; Hahamis et al., 2005; Ganapati and Reddick, 2014; Alexopoulos et al., 2018). On the other hand, according to Goulas and Kontogeorga (2009), the e-government is not at an advanced stage due to the lack of exploitation of EU funding programmes and that is also confirmed by the survey conducted. According to this, almost half of the municipalities spend their own money and a very small percentage of third-party funding. Except for the above, there are also other obstacles like the bandwidth issues (Hahamis et al., 2005), staff resistance (Ruano de la Fuente, 2014), lack of inter-departmental collaboration, lack of stakeholder interest and information about e-government apps as well as privacy-security issues.

Although the real e-government benefits are impossible to quantify Alketbi (2018), the findings of this survey show that municipality' representatives believe that the two greatest benefits are improvement of citizen services and communication with the public (Ganapati and Reddick, 2014; Munoz and Bolivar, 2018). This is fully in line with the motive of improving the efficiency of the flow of information with the external environment. Other benefits include reducing time requirements as well as streamlining administrative procedures to become more effective and changing staff roles.

Having gained knowledge of what motivates Municipalities, the obstacles they encounter, as well as some factors that favor the implementation of e-government, it would be easy to record some steps that lead to the creation of a successful application. In a rapidly changing environment, it is necessary for administrations to take a step backwards and rethink their goals and strategies for e-government. In addition to adding "e", an integrated policy approach is needed to help organizations avoid failures and address barriers and risks (Muñoz and Bolivar, 2018).

Results also show that some municipalities are implementing e-government far better than others. That means that there is a long way to go in achieving active, online governance that will enable the provision of interactive services responsive to citizens' needs. A more particular attention to the launch of e-government project and a more formal strategic planning specifically for e-government, with clear goals and roles description of the parties involved would allow municipalities to establish goals for higher e-government level. Competition may not always have the desired results, as mimesis is often limited to a focus on the characteristics of other organizations without taking into account the objectives that they want to achieve (Karkin and Janssen, 2014).

The first step for municipalities towards a successful e-government implementation should be the clarification of the requirements of both parties. This implies extensive research of the existing system and feedback from both end-users and employees who are using the legacy system that must be assembled. Comprehensive consultations will lead to a clear vision and a coherent plan which is the starting point for change. The lack of a strategic plan for e-government is a deterrent and the 
bigger the distance between planning and reality distance, the greater are the chances for failure (Alketbi, 2018). More specifically, some recommendations for successful implementation could be formulated, such as an early planning and action to address the lack of technical skills and experience of the municipal staff, to deal with their resistance and to secure revenues or third-party funding. In general, there should be organizational and institutional changes, staff training in new technologies, reorganization of administrative processes, building citizen and employee confidence, increased awareness about the needs of citizens and securing the support of elected officials.

There are three main limitations of the study. The main point is that while egovernment has been subject for many researches, there is still no extensive research in the field of motivation. Therefore, results are not easily verifiable and comparable which can result in the support of unreliable motivations and the omission of others. Second, three extensions were given for the collection of data because of the local government elections. These persistent requests may have resulted in responses that did not give the necessary weight and provided inconsistent information. Third, the data used by ELSTAT was related to the 2011 census. It is suggested future research to explore other motivations and factors, as well as to use the qualitative approach for a more detailed picture but also to focus on the regions of the country. Lastly, it would be useful to evaluate the benefits to operators after implementation and to identify citizen' perceptions.

\section{Reference:}

Alcaraz-Quiles, F.J., Navarro-Galera, A., Ortiz-Rodríguez, D. 2015. Factors determining online sustainability reporting by local governments. International Review of Administrative Sciences, 81(1), 79-109.

Alexopoulos, C., Charalabidis, Y., Kolokotronis, D.E., Vogiatzis, N. 2018. A taxonomy for analysing smart cities developments in Greece. Proceedings of the $11^{\text {th }}$ International Conference on Theory and Practice of Electronic Governance, ICEGOV, 537-549.

Alketbi, H. 2018. An Evaluation of E-government Effectiveness in Dubai Smart Government Departments. Thesis Southampton Solent University.

Andrisani, R.J., Hakim, S., Savas, E.S. 2002. The New Public Management, Lessons from Innovating Governors and Mayors. Spinger Science+Business Media, New York.

Arduini, D., Belotti, F., Denni, M., Giungato, G., Zanfei, A. 2010. Technology adoption and innovation in public services the case of e-government in Italy. Information Economics and Policy, 22(3), 257-275.

Arduini, D., Denni, M., Lucchese, M., Nurra, A., Zanfei, A. 2013. The role of technology, organization and contextual factors in the development of e-Government services: An empirical analysis on Italian Local Public Administrations. Structural Change and Economic Dynamics, 27, 177-189.

Baines, S., Wilson, R., Walsh, S. 2010. Seeing the full picture? Technologically enabled multi-agency working in health and social care. New Technology, Work and Employment, 25(1), 19-33.

Beldad, A., Jong, M., Steehouder, M. 2010. Reading the least read? Indicators of users' intention to consult privacy statements on municipal websites. Government 
Information Quarterly, 27, 238-244.

Bennett, L.V., Manoharan, A.P. 2017. The Use of Social Media Policies by US Municipalities. International Journal of Public Administration, 40(4), 317-328.

Bernhard, I., Wihlborg, E. 2015. Municipal Contact Centres: A Slower Approach Towards Sustainable Local Development by E-government. European Planning Studies, 23(11), 2292-2309.

Beynon-Davies, P., Martin, S. 2004. Electronic local government and the modernisation agenda: Progress and prospects for public service improvement. Local Government Studies, 30(2), 214-229.

Bolivari, M.P.R. 2018. User Centric Services Under the Web 2.0 Era. Coproduction, Execution and Efficiency of Public Services. In Saeed, S., Ramayah, T., Mahmood, Z. (Eds) User Centric E-government. Challenges and Opportunities, Springer, Switzerland, 137-158.

Bonsón, E., Royo, S., Ratkai, M. 2015. Citizens' engagement on local governments' facebook sites. an empirical analysis: The impact of different media and content types in western Europe. Government Information Quarterly, 32(1), 52-62.

Bonsón, E., Torres, L., Royo, S., Flores, F. 2012. Local e-government 2.0: Social media and corporate transparency in municipalities. Government Information Quarterly, 29(2), 123-132.

Calista, D.J., Melitski, J., Holzer, M., Manoharan, A. 2010. Digitized government in worldwide municipalities between 2003 and 2007. International Journal of Public Administration, 33(12), 588-600.

Carrizales, T., Melitski, J., Manohara, A., Holzer, M. 2011. E-Governance Approaches at the Local Level: A Case Study in Best Practice. International Journal of Public Administration, 34(14), 935-945.

Cegarra-Navarro, J.G., Pachón, J.R.C., Cegarra, J.L.M. 2012. E-government and citizen's engagement with local affairs through e-websites: The case of Spanish municipalities. International Journal of Information Management, 32(5), 469-478.

Chen, A.J., Pan, S.L., Zhang, J., Huang, W.W., Zhu, S. 2009. Managing e-government implementation in China: A process perspective. Information and Management, 46(4), 203-2012.

Choudrie, J., Ghinea, G., Songouga, V.N. 2013. Silver surfers, e-government and the digital divide: An exploratory study of UK local authority websites and older citizens. Interacting with Computers, 25(6), 417-442.

Costopoulou, C., Ntalianis, F., Ntaliani, M., Karetsos, S., Gkoutzioupa, E. 2017. Eparticipation Provision and Demand Analysis for Greek Municipalities. Proceedings of the $7^{\text {th }}$ International Conference, E-Democracy, 3-14.

Criado, J.I., Ramilo, M.C. 2003. E-government in practice: An analysis of web site orientation to the citizens in Spanish municipalities. International Journal of Public Sector Management, 16(3), 191-218.

Cumbie, B.A., Kar, B. 2016. A Study of Local Government Website Inclusiveness: The Gap Between E-government Concept and Practice. Information Technology for Development, 22(1), 15-35.

Deakins, E., Dillon, S.M. 2002. E-government in New Zealand: The local authority perspective. International Journal of Public Sector Management, 15(4-5), 375-398.

Fan, B., Luo, J. 2014. Benchmarking scale of e-government stage in Chinese municipalities from government chief information officers' perspective. Information Systems and e-Business Management, 12(2), 259-284.

Fan, Q. 2011. An Evaluation Analysis of E-government Development by Local Authorities 
in Australia. International Journal of Public Administration, 34(14), 926-934.

Feeney, M.K., Brown, A. 2017. Are small cities online? Content, ranking, and variation of U.S. municipal websites. Government Information Quarterly, 34(1), 62-74.

Feller, J., Finnegan, P., Nilsson, O. 2011. Open innovation and public administration: Transformational typologies and business model impacts. European Journal of Information Systems, 20(3), 358-374.

Ferro, E., Sorrentino, M. 2010. Can intermunicipal collaboration help the diffusion of EGovernment in peripheral areas? Evidence from Italy. Government Information Quarterly, 27(1), 17-25.

Field, A. 2009. Discovering Statistics Using SPSS. 3rd Edition, Sage Publications Ltd., London.

Ford, N., Murphy, G. 2008. Evaluating the potential of a web-based portal to support the leverage of professional expertise across local authority boundaries. Local Government Studies, 34(3), 397-418.

Fountain, J.E. 2006. Enacting Technology in Networked Governance: Developmental Processes of Cross-Agency Arrangements. National Center for Digital Government Working Paper Series, 6(3).

Gallego-Alvarez, I., Rodríguez-Domínguez, L., García-Sánchez, I.M. 2010. Are determining factors of municipal E-government common to a worldwide municipal view? An intra-country comparison. Government Information Quarterly, 27(4), 423-430.

Ganapati, S., Reddick, C.G. 2014. The use of ICT for open government in U.S. municipalities: Perceptions of chief administrative officers. Public Performance and Management Review, 37(3), 365-387.

Garrett, P.M. 2005. Social work's 'electronic turn': Notes on the deployment of information and communication technologies in social work with children and families. Critical Social Policy, 25(4), 529-553.

Gilbert, D., Balestrini, P., Kolsaker, A., Littleboy, D. 2007. Citizen Adoption of eGovernment in the UK: Perceived Benefits and Barriers. In Griffin, D., Trevorrow, P., Halpin, E. (Eds), Developments in e-Government, A Critical Analysis, IOS, Netherlands, 168-181.

Goulas, D.S., Kontogeorga, G.N. 2009. EGovernment appliance problems on first degree self-government of Greece. Proceedings of the 15th Annual Scientific Conference on Web Technology, New Media Communications and Telematics Theory Methods, Tools and Applications, EUROMEDIA, 96-100.

Griffin, D. 2007. How Does e-Government Innovation Affect Local Government's Accountability to the Public? In Griffin, D., Trevorrow, P., Halpin E. (Eds), Developments in e-Government, A Critical Analysis, IOS, Netherlands, 112-125.

Gritzalis, A., Tsohou, A., Lambrinoudakis, C. 2017. Transparency-Enabling Systems for Open Governance: Their Impact on Citizen's Trust and the Role of Information Privacy. Proceedings of the $7^{\text {th }}$ International Conference, E-Democracy, 47-63.

Hahamis, P., Iles, J., Healy, M. 2005. e-Government in Greece: Opportunities for improving the efficiency and effectiveness of local government. Proceedings of the 5th European Conference on e-Government, ECEG 2005, 203-212.

Homburg, V., Dijkshoorn, A., Thaens, M. 2014. Diffusion of Personalised Services among Dutch Municipalities: Evolving Channels of Persuasion. Local Government Studies, 40(3), 429-450.

Hood, C. 1991. A Public Management for all seasons? Public Administration, 69, 3-19.

Hultèn, P., Björkstrand, H. 2009. A case study of the development of an e-service for the Swedish mining industry. Services Marketing Quarterly, 30(1), 18-38. 
Jun, K.N., Weare, C. 2011. Institutional motivations in the adoption of innovations: The case of e-government. Journal of Public Administration Research and Theory, 21(3), 495-519.

Kamal, M.M., Weerakkody, V., Jones, S. 2009. The case of EAI in facilitating e-Government services in a Welsh authority. International Journal of Information Management, 29(2), 161-165.

Karakikla, A., Karakiklas, D. 2013. E-government. Dissertation for MSc, Piraeus University of Applied Sciences Technological Educational Institute of Piraeus.

Karkin, N., Janssen, M. 2014. Evaluating websites from a public value perspective: A review of Turkish local government websites. International Journal of Information Management, 34(3), 351-368.

King, S.F. 2007. Citizens as customers: Exploring the future of CRM in UK local government. Government Information Quarterly, 24(1), 47-63.

Kubicek, H., Cimander, R., Scholl, H.J. 2011. Organizational Interoperability in EGovernment, Lessons from 77 European Good-Practice Cases, Spinger, USA.

Lampathaki, F., Kroustalias, N., Koussouris, S., Charalabidis, Y., Psarras, J. 2010. Implementing interoperability infrastructures: Issues and challenges from the citizens' base registry in Greece. Proceedings of the 43rd Hawaii International Conference on System Sciences, HICSS, 1-10.

Lappas, G., Triantafillidou, A., Kleftodimos, A., Yannas, P. 2015. Evaluation framework of local e-government and e-democracy: A citizens' perspective. Proceeding of the Conference on e-Learning, e-Management and e-Services, IEEE, 181-186.

Lev-On, A., Steinfeld, N. 2015. Local engagement online: Municipal Facebook pages as hubs of interaction. Government Information Quarterly, 32(3), 299-307.

Luo, M.M., Chea, S. 2018. Internet Village Motoman Project in rural Cambodia: bridging the digital divide. Information Technology and People, 31(91), 2-20.

Ma, L. 2013. The Diffusion of Government Microblogging: Evidence from Chinese municipal police bureaus. Public Management Review, 15(2), 288-309.

Ma, L. 2014. Diffusion and Assimilation of Government Microblogging: Evidence from Chinese cities. Public Administration Review, 16(2), 274-295.

Manoharan, A., Fudge, M., Zheng, Y. 2015. Global Clusters in Municipal E-Governance: A Longitudinal Study. International Journal of Public Administration, 38(2), 116-131.

Moon, M.J. 2002. The evolution of E-government among municipalities: Rhetoric or reality? Public Administration Review, 62(4), 424-433.

Munoz, L.A., Bolivar, M.P.R. 2018. Experiences of E-Government Development Implementation in Developing Countries: Challenges and Solutions. In Munoz, L.A., Bolivar, M.P.R. (Eds), International E-Government Development. Policy. Implementation and Best Practice, Palgrave Macmillan, Switzerland, 3-18.

Nasi, G., Frosini, F., Cristofoli, D. 2011. Online service provision: Are municipalities really innovative? The case of larger municipalities in Italy. Public Administration, 89(3), 821-839.

Ochara, N.M. 2010. Assessing irreversibility of an E-Government project in Kenya: Implication for governance. Government Information Quarterly, 27(1), 89-97.

Petroudes, A.I. 2017. Spatial inequalities of income in Greece. Dissertation for MSc, University of Piraeus.

Picci, L. 2006. The quantitative evaluation of the economic impact of e-government: A structural modelling approach. Information Economics and Policy, 18(1), 107-123.

Pina, V., Torres, L., Royo, S. 2007. Are ICTs improving transparency and accountability in the EU regional and local governments? An empirical study. Public Administration, 
$85(2), 449-472$.

Pollitt, C., Bouckaert, G. 2011. Public Management Reform: A Comparative Analysis-New Public Management, Governance, and the Neo-Weberian State. $3^{\text {rd }}$ edition, Oxford University Press, New York.

Previtali, P., Bof, F. 2009. E-government adoption in small Italian municipalities. International Journal of Public Sector, 22(4), 338-348.

Reddick, C.G. 2004. A two-stage model of e-government growth: Theories and empirical evidence for U.S. cities. Government Information Quarterly, 21(1), 51-64.

Reddick, C.G. 2007. E-Government Adoption in Canadian Municipal Governments: A Survey of Ontario Chief Administrative Officers. In Norris, D.E. (Eds), Current issues and trends in E-government Research, Cyber Tech Publishing, Hershey, 289308.

Reddick, C.G., Norris, D.F. 2013a. E-participation in local governments: An examination of political managerial support and impacts. Transforming Government People, Process and Policy, 7(4), 453-476.

Reddick, C.G., Norris, D.F. 2013b. Social media adoption at the American grass roots: Web 2.0 or 1.5? Government Information Quarterly, 30(4), 498-507.

Reggi, L., Arduini, D., Biagetti, M., Zanfei, A. 2014. How advanced are Italian regions in terms of public e-services? the construction of a composite indicator to analyze patterns of innovation diffusion in the public sector. Telecommunications Policy, 38(5/6), 514-529.

Rooks, G., Matzat, U., Sadowski, B. 2017. An empirical test of stage models of egovernment development: Evidence from Dutch municipalities. Information Society, 33(4), 215-225.

Rose, J., Persson, J.S., Heeager, L.T., Irani, Z. 2015. Managing e-Government: Value positions and relationships. Information Systems Journal, 25(5), 531-571.

Rossel, P., Finger, M. 2007. Conceptualizing e-governance. Proceedings of the 1st International conference on Theory and practice of electronic governance, ICEGOV, 2007, 399-407.

Ruano de la Fuente, J.M. 2014. E-Government Strategies in Spanish Local Governments. Local Government Studies, 40(4), 600-620.

Rufin, R., Medina, C., Sánchez Figueroa, J.C. 2012. Moderating Factors in Adopting Local e-Government in Spain. Local Government Studies, 38(3), 367-385.

Sandoval-Almazan, R., Gil-Garcia, J.R. 2012. Are government internet portals evolving towards more interaction, participation, and collaboration? Revisiting the rhetoric of e-government among municipalities. Government Information Quarterly, 29(1), $572-581$.

Schedler, K., Summermatter, L. 2007. Customer orientation in electronic government: Motives and effects. Government Information Quarterly, 24(2), 291-311.

Seo, D., Bernsen, M. 2016. Comparing attitudes toward e-government of non-users versus users in a rural and urban municipality. Government Information Quarterly, 33(2), 270-282.

Thompson, C.S. 2002. Enlisting on-line residents: Expanding the boundaries of egovernment in a Japanese rural township. Government Information Quarterly, 19(2), 173-187.

Van Der Wee, M., Verbrugge, S., Sadowski, B., Driesse, M., Rickavet, M. 2015. Identifying and quantifying the indirect benefits of broadband networks for e-government and ebusiness: A bottom-up approach. Telecommunications Policy, 39(3/4), 176-191.

van Loon, A., Toshkov, D. 2015. Adopting open source software in public administration: 
The importance of boundary spanners and political commitment. Government Information Quarterly, 32(2), 207-215.

Warf, B. 2014. Asian geographies of e-government. Eurasian Geography and Economies, 55(1), 94-110.

Webster, C.W.R. 2007. Myths, Rhetoric and Policy in the Information Age: The Case of Closed Circuit Television. In Griffin, D., Trevorrow, P., Halpin E. (Eds),

Developments in e-Government, A Critical Analysis, IOS, Netherlands, 16-30.

Windrum, P. 2008. Conclusions: public innovation and entrepreneurship. In Windrum, P., Koch, P. (Eds), Innovation in Public Sector Services, Entrepreneurship, Creativity and Management, Edward Elgar, UK, 228-243.

Xia, J. 2010. Linking ICTs to rural development: China's rural information policy. Government Information Quarterly, 27(2), 187-195.

Young, S.C. 2015. Factors affecting the Adoption of New Technology: the case of 311 Government Call Centers. Dissertation for PhD, Florida International University.

Youngblood, N.E., MacKiewicz, J. 2012. A usability analysis of municipal government website home pages in Alabama. Government Information Quarterly, 29(4), 582588.

Yu, Y. 2015. An empirical analysis of the relationship between environmental performance and sustainable e-governance in China. Technological Forecasting and Social Change, 96, 71-78.

Appendix Table 1. E-government ranking per Municipality and population

\begin{tabular}{|l|l|l|l|l|l|}
\hline Municipality name & $\begin{array}{l}\text { E-gov } \\
\text { ranking }\end{array}$ & Population & Municipality name & $\begin{array}{l}\text { E-gov } \\
\text { ranking }\end{array}$ & Population \\
\hline $\begin{array}{l}\text { MOLOS-AG. } \\
\text { KONSTANTINOS }\end{array}$ & 37 & 12.090 & SERRES & 19 & 76.817 \\
\hline KEA & 36 & 2.455 & AGRINIO & 19 & 94.181 \\
\hline LAMIA & 34 & 75.315 & RHODES & 18 & 115.490 \\
\hline CHALKIDONA & 31 & 33.673 & ILIDA & 18 & 32.219 \\
\hline CHANIA & 30 & 108.642 & KEFALLONIA & 18 & 35.801 \\
\hline SITIA & 30 & 18.318 & ALEXANDRIA & 18 & 41.570 \\
\hline METAMORFOSSI & 29 & 29.891 & ATHENS & 18 & 664.046 \\
\hline ELEFSINA & 29 & 29.902 & ELAFONISOS & 17 & 1.041 \\
\hline KAVALA & 29 & 70.501 & OICHALIA & 17 & 11.228 \\
\hline KOS & 28 & 33.388 & THASSOS & 17 & 13.770 \\
\hline XANTHI & 28 & 65.133 & POLYGYROS & 17 & 22.048 \\
\hline TRIKALA & 28 & 81.355 & PAGGAIO & 17 & 32.085 \\
\hline HERAKLION & 27 & 173.993 & THIVA & 17 & 36.477 \\
\hline PENTELI & 27 & 34.934 & KILKIS & 17 & 51.926 \\
\hline DESKATI & 27 & 5.852 & AG. DIMITRIOS & 17 & 71.294 \\
\hline AMFIKLIA & 26 & 10.922 & SKOPELOS & 16 & 4.960 \\
\hline
\end{tabular}




\begin{tabular}{|c|c|c|c|c|c|}
\hline NAXOS & 26 & 18.864 & KORDELIO-VOSMOS & 15 & 101.753 \\
\hline ORAIOKASTRO & 26 & 38.317 & TEMPON & 15 & 13.712 \\
\hline ANTIPAROS & 25 & 1.211 & IASMOS & 15 & 13.810 \\
\hline TRIFYLIA & 25 & 27.373 & ALMYROS & 15 & 18.614 \\
\hline ALEXANDROUPOLI & 25 & 72.959 & AVDERA & 15 & 19.005 \\
\hline NEAPOLI-SYKIES & 25 & 84.741 & PHILOTHEI PSYCHIKO & 15 & 26.968 \\
\hline APSROPYRGOS & 24 & 30.251 & NAFPAKTOS & 15 & 27.800 \\
\hline LEVADIA & 24 & 31.315 & FYLI & 15 & 45.965 \\
\hline ZIROS & 23 & 13.892 & THERMAIKOS & 15 & 50.264 \\
\hline THESSALONIKI & 23 & 325.182 & KORYDALLOS & 15 & 63.445 \\
\hline SKIATHOS & 23 & 6.088 & PAROS & 14 & 13.715 \\
\hline MAROUSSI & 23 & 72.333 & AGATHONISI & 14 & 185 \\
\hline IOANNINA & 22 & 112.486 & PYLOS NESTOR & 14 & 21.077 \\
\hline KILELER & 22 & 20.854 & LOUTRAKI & 14 & 21.221 \\
\hline ALIMOS & 22 & 41.720 & AGIOS NIKOLAOS & 14 & 27.074 \\
\hline TANAGRA & 21 & 19.432 & PAIONIA & 14 & 28.493 \\
\hline NESTOS & 21 & 22.331 & ELASSONA & 14 & 32.121 \\
\hline HERSONISSOS & 21 & 26.717 & NEA PROPONTIDA & 14 & 36.500 \\
\hline NAFPLIO & 21 & 33.356 & VOREIA TZOUMERKA & 14 & 5.714 \\
\hline ORESTIADA & 21 & 37.695 & ELLINIKO & 14 & 51.356 \\
\hline EORDAIA & 21 & 45.592 & PERISTERI & 13 & 139.981 \\
\hline DRAMA & 21 & 58.944 & SERVION - VELVENTOU & 13 & 14.830 \\
\hline ALIARTOS & 20 & 10.887 & AIGIALEIA & 13 & 49.872 \\
\hline ARCHAIAS OLYMPIAS & 20 & 13.409 & TINOS & 13 & 8.636 \\
\hline SINTIKI & 20 & 22.195 & MYKIS & 12 & 15.540 \\
\hline DELPHI & 20 & 26.716 & KALYMNOS & 12 & 16.179 \\
\hline ARGOS-MYCENAE & 20 & 42.022 & 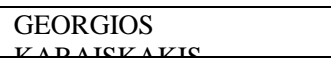 & 12 & 5.780 \\
\hline TRIPOLI & 20 & 47.254 & XIROMEROU & 11 & 11.737 \\
\hline VIANNOS & 20 & 5.563 & MANTOUDIOU-LIMNIS & 11 & 12.045 \\
\hline ZAGORA-MOURESI & 20 & 5.809 & FARKADONA & 10 & 13.396 \\
\hline CHIOS & 20 & 51.390 & MYLOPOTAMOS & 10 & 14.363 \\
\hline ILIOUPOLI & 20 & 78.153 & GREVENA & 10 & 25.905 \\
\hline KATERINI & 20 & 85.851 & ITHAKI & 10 & 3.231 \\
\hline LESVOS & 20 & 86.436 & MOUZAKI & 9 & 13.122 \\
\hline TOPEIROS & 19 & 11.544 & NIKOLAOS SKOUFAS & 8 & 12.753 \\
\hline DIRFYS MESSAPIA & 19 & 18.800 & ZAKYNTHOS & 8 & 40.759 \\
\hline AGIA VARVARA & 19 & 26.550 & AEGINA & 6 & 13.056 \\
\hline ALMOPIA & 19 & 27.556 & SAMOTHRAKI & 6 & 2.859 \\
\hline KOMOTINI & 19 & 66.919 & & & \\
\hline
\end{tabular}


Appendix Table 2. Provided services on website

\begin{tabular}{|c|c|c|}
\hline Provided services on website & YES & NO \\
\hline Press Releases & 109 & \\
\hline General information about the Municipality and historical background & 107 & 2 \\
\hline Contact information for Mayor and city council members (email, phone, address) & 94 & 15 \\
\hline Online employment information (e.g. openings and application procedures) & 93 & 16 \\
\hline Contact form & 92 & 17 \\
\hline $\begin{array}{l}\text { Central directory with all employees listed with contact information that enable citizens to find a } \\
\text { particular person }\end{array}$ & 85 & 24 \\
\hline $\begin{array}{l}\text { Online announcement of City Council meetings, invitation of citizens and form of comments on } \\
\text { the agenda to be discussed }\end{array}$ & 84 & 25 \\
\hline $\begin{array}{l}\text { Description, activities or events of municipal departments/organizations/units (central } \\
\text { site/directory rather than having to go to departments) }\end{array}$ & 83 & 26 \\
\hline Description of current and new projects (budget, designs, cost estimates) & 75 & 34 \\
\hline Online submission of complaints, comments, reports and proposals & 72 & 37 \\
\hline There an easy to use searchable database/search bar & 67 & 42 \\
\hline Links to Municipality’ social media (Facebook, Twitter or Youtube) & 65 & 44 \\
\hline User registration to the municipal website & 64 & 45 \\
\hline Mayor and council members' financial statements & 63 & 46 \\
\hline Text or video of major speeches of mayor or deputy mayor, or city council chair & 62 & 47 \\
\hline Districts maps & 62 & 47 \\
\hline Information about elections & 60 & 49 \\
\hline Information about the weather & 56 & 53 \\
\hline Privacy statement/policy or disclaimer with a privacy section & 55 & 54 \\
\hline Published date on main page & 51 & 58 \\
\hline Search bar by outside provider (e.g. Google or Bing) & 49 & 60 \\
\hline Online video, audio podcast, video webcast, or live feed of council meetings & 48 & 61 \\
\hline Geographic Information System Data (GIS) & 46 & 63 \\
\hline Versions of the site in other languages & 44 & 65 \\
\hline Disabled persons accessibility & 41 & 68 \\
\hline $\begin{array}{l}\text { Statement or advertisement declaring that the site is development or maintained by outside } \\
\text { contractor }\end{array}$ & 40 & 69 \\
\hline RSS feed & 39 & 70 \\
\hline Online application for licenses, permits, certifications, etc (citizens and business) & 38 & 71 \\
\hline Public transportation options and schedules (i.e., bus routes) & 36 & 73 \\
\hline Blog, discuss board, forum & 32 & 77 \\
\hline Online voting and polls & 30 & 79 \\
\hline $\begin{array}{l}\text { Searchable index or list for archived laws, regulations, and requirements (includes municipal } \\
\text { code) }\end{array}$ & 25 & 84 \\
\hline $\begin{array}{l}\text { Link or text of public information law about Freedom of Information Act/FOIA (this includes } \\
\text { requesting access to files/ records requests }\end{array}$ & 23 & 86 \\
\hline $\begin{array}{l}\text { Direct link or access to transactional opportunities such as paying bills or parking tickets, taxes, } \\
\text { fines, debts (citizens or business) }\end{array}$ & 22 & 80 \\
\hline Ability to report online police misconduct such as graffiti, burglary, vandalism etc. & 22 & 87 \\
\hline Online application form and registration for a job & 18 & 91 \\
\hline Videoconferencing with municipal agencies/council members & 10 & 99 \\
\hline Information about fuel prices & 4 & 105 \\
\hline
\end{tabular}

